\title{
KONVERSI AGAMA, PERTUMBUHAN, DAN ORIENTASI KEAGAMAAN (Studi Kasus di KUA Gondangrejo Karanganyar Tahun 2015-2017)
}

\author{
Ida Hamidah \\ Penyuluh Agama Islam Fungsional Kankemenag Kab.Karanganyar \\ e-mail: zamoormusafi@yahoo.co.id
}

\begin{abstract}
Abstrak: Konversi agama sebagai hak yang melekat dalam diri individu dalam praktiknya tidak selalu mudah, akan tetapi mengalami berbagai tantangan. Dalam kasus konversi di Gondangrejo Karanganyar persoalan konversi tidak lepas dari adanya pertumbuhan keberagamaan yang dialami oleh seseorang. Perkembangan keberagamaan seseorang secara umum dibedakan menjadi healty minded dan sick Soul. Bagi Orang yang memiliki kepribadian sick soul dengan segala kepasrahan kepada Tuhan membuat mereka menjadi orang yang tidak mudah menyalahkan atau menuntut orang lain. Sedangkan orang dengan kepribadian healty minded memiliki kecenderungan memiliki pandangan keberagamaan yang terbuka, mau menerima pola keberagamaan orang lain yang beda dengan dirinya. Sedangkan orientasi keberagamaan seseorang dalam kasus Gondangrejo ini mengarahkan seseorang menciptakan sistem makna untuk mengarahkan perilaku kesalehan dalam kehidupan, yang puncaknya pada kematangan beragama.
\end{abstract}

Kata kunci: konversi agama, orientasi keagamaan, KUA Gondangrejo

\section{PENDAHULUAN}

Agama muncul di tengah kehidupan manusia sebagai pengalaman yang bersifat personal sekaligus pengalaman sosial. Sebagai pengalaman yang bersifat personal agama selalu dihubungkan dengan apa yang diimani seseorang secara pribadi, bagaimana agama difungsikan dalam kehidupan, bagaimana pengaruh agama dalam berpikir seseorang dan bagaimana nilai- nilai agama mempengaruhi tingkah laku seseorang. Sedangkan sebagai pengalaman sosial seseorang agama dapat dilihat pada berbagai karakteristik, watak dan prilaku keberagamaan sebuah kelompok sosial keagamaan (Jalaluddin Rahmat, 2003: 3233). Dalam kedua pengalaman ini agama memiliki arti sebagai sarana mengungkapkan berbagai perasaan, tindakan, dan pengalaman manusia secara individual dalam keheningan mereka, sejauh mereka memahami diri mereka berada dalam hubungan dengan apa pun yang mereka pandang sebagai yang "ilahi”.

Pertumbuhan kematangan beragama selalu berproses secara terus menerus yang seringkali disertai dengan gejala-gejala ketidak sempurnaan, ketidak seimbangan, kemuraman, depresi, rasa berdosa, kecemasan, ketegangan yang berkaitan dengan keraguan keraguan disatu sisi. Namun, disisi lainnya terdapat pula adanya kelegaan dan objektifitas yang membahagiakan, seperti keyakinan dari yang tumbuh berkat penyesuaian antara daya yang dimilikinya dengan cara pandang yang luas (James, 2004: 293). Di sinilah Perasaan cemas, berdosa, tertekan dan lainnya yang melingkupi seseorang memungkinkan orang tersebut melakukan ikhtiar untuk mengatasinya melalui usaha yang bisa memunculkan kelegaan hati dan ketentraman dalam jiwa seseorang. 
Salah satu kematangan beragama seseorang ditunjukkan dengan kesadaran untuk melakukan konversi agama, atau perpindahan agama satu keagama lainnya. Dalam doktrin agama, secara umum konversi ini mendapatkan kecaman yang keras, dengan penyebutan yang tak kalah kerasnya juga. Islam menyebut konversi agama sebagai "pemurtadan" atau apostad. Namun dalam tinjauan hak Azasi Manusia (HAM) melakukan pilihan agama berdasarkan pada keyakinan dan kesadaran diri adalah persoalan yang harus dihormati oleh siapapun juga. Dalam HAM pilihan agama adalah hak pokok atau hak dasar yang dibawa oleh manusia sejak lahir yang secara kodrat melekat pada setiap manusia dan tidak dapat diganggu gugat karena merupakan anugerah Tuhan Yang Maha Esa. Tidak boleh atas nama HAM kemudian mengabaikan hak-hak yang sifatnya sangat personal.

Di Indonesia dalam UUD 45 Pasal 28 (1) disebutkan bahwa “...hak untuk hidup, hak untuk tidak disiksa, hak kemerdekaan pikiran, dan hati nurani, hak beragama, hak untuk tidak diperbudak, hak untuk diakui sebagai pribadi dihadapan hukum,dan hak untuk tidak dituntut atas dasar hukum yang berlaku surut adalah hak asasi manusia yang tidak dapat dikurangi dalam keadaan apapun". Berangkat dari kondisi di atas studi mengenai konversiagama yang terjadi di KUA Kecamatan Gondangrejo Kabupaten Karanganyar menjadi penting.

\section{PEMBAHASAN}

\section{Paparan Konversi di Kecamatan Gondangrejo Karanganyar}

Jumlah penduduk di Kecamatan Gondangrejo sampai pada pada tahun 2017 sebanyak 76.072 jiwa, dengan penduduk muslim 72.007(97\%) dan penduduk non muslim 4.065 (3\%). Jumlah penduduk ini tersebar di 13 kelurahan yang meliputi Plesungan, Wonorejo, Jeruksawit, Jatikuwung, Selokaton, Rejosari, Bulurejo, Tuban, Krendowahono, Dayu, Wonosari, Karangturi, Kragan. Masing-masing desa di Gondangrejo menunjukkan adanya karakteristik yang variatif, tergantung pada posisi wilayahdesa yang bersangkutan serta kebijakan pembangunan pemerintah. Dari 13 desa tersebut,ada 1 wilayah desa memiliki penduduk 100\% muslim, yaitu Desa Krendowahono. Sedangkan Jeruksawit, Jatikuwung, Rejosari, Bulurejo, Tuban, Dayu, Wonosari, Karangturi, Kragandi masing-masing desa tersebut ada sedikit penduduk non- muslimnya. Sedangkan desa yang penduduk nonmuslimnya terbanyak adalah Selokaton, Plesungan dan Wonorejo.

Di Kecamatan Gondangrejo organisasi keagamaan yang terbesar, yang dianut oleh masyarakat di Kecamatan Gondangrejo adalah Nahdlatul Ulama (NU) dan Muhammadiyah. Kedua organisasi ini mempunyais truktur yang baik sampai dengan ranting, atau tingkat desa. Kehidupan sosial warga berjalan dengan baik, dimana warga masyarakat bekerja sama,saling menghormati, dan saling menghargai antara yang satu dengan yang lain. Selain tersedianya masjid, sebagai sarana beribadah, juga terdapat gereja. Distribusi sarana ibadah masingmasing desa memiliki persentase yang beragam. Tiga desa, yaitu Wonorejo, Selokaton dan Plesungan memiliki jumlah masjid terbanyak, masing-masing 26, 20 dan 17 masjid.

Untuk Musholla Desa Tuban memiliki jumlah terbanyak, yakni 28 Musholla, kemudian disusul Desa Selokaton, Wonorejo, Kragan masing-masing mempunyai jumlah 45 Musholla. Sarana Ibadah yang berupa Musholla hampir di masing-masing RW atau RT ada. Hal ini sebenarnya sangat menguntungkan masyarakat karena mereka akan lebih mudah dan lebih dekat apabila akan menunaikan ibadah, khususnya shalat berjamaah. 
Mereka tidak perlu jauh-jauhpergi ke daerah lain karena di lingkungan sendiri sudah tersedia. Sedangkan Gereja juga ada di beberapa desa di wilayah Kec. Gondangrejo, seperti di Ds. Plesungan ada 3 Gereja, Desa Wonorejo ada 6 Gereja, Rejosari 1 dan juga Selokaton ada 4 Gereja.

Selama tiga tahun terakhir (2015-2017) di kecamatan Gondangrejo terjadi 45 kali peristiwa konversi agama dengan princian tahun 2015 ada 10 kasus, 2016 ada 19 kasus dan pada tahun 2017 ada 16 kasus konversi antar agama, dengan latar belakang alasan dan perkembangan yang berbeda- beda. Konversi ini secara makanis berjalan dengan sangat mudah, sebab KUA sebagai ujung tombak kementerian agama tidak menetapkan syarat yang ketat. Secara umum syarat dan alur masuk Islam KUA (Kantor Urusan Agama) Kecamatan Gondangrejo adalah dengan melengkapi, pertama surat pengantar dari desa yang berisi kehendak pindah agama dari agama sebelumnya. Kedua, Surat pernyataan/permohonan masuk Islam bermaterai yang ditanda tangani oleh yang bersangkutan disaksikan 2 orang tokoh masyarakat, yang didalamnya berisikan bahwa yang bersangkutan masuk Islam secara sukarela tanpa adanya paksaan atau tekanan dari pihak lain. Ketiga, surat keterangan telah mengucapkan ikrar Syahadat dari Takmir Masjid terdekat dari tempat tinggal pemohon ditandangani oleh ketua Takmir masjid tersebut dan juga pemohon serta 2 orang saksi. Keempat adanya foto copi KTP (Kartu Tanda Penduduk) dan KK (Kartu Keluarga). Kelima,Pas foto ukuran 4x6 sebanyak 2 lembar. (6) Surat baptis asli( Jika sudah punya).

Syarat- syarat tersebut bertujuan agar muallaf yang bersangkutan mendapatkan bimbingan tidak hanya dari KUA akan tetapi berkelanjutan oleh tokoh masyarakat terdekat. Mulai dari Rt, Rw, Perangkat Desa dan Tokoh Agama turut andil dalam pendampingan serta membantu proses Konversi Agama warganya tersebut. Konversi agama banyak menyangkut masalah kejiwaan dan pengaruh lingkungan tempat berada. Selain itu konversi agama yang dimaksudkan dari beberapa pendapat di atas memuat beberapa pengertian dengan ciri ciri :

a. Adanya perubahan arah pandangan dan keyakinan seseorang terhadap agama dan kepercayaan yang dianutnya.

b. Perubahan yang terjadi dipengaruhi kondisi kejiwaan sehingga perubahan dapat terjadi secara berproses atau secara mendadak.

c. Perubahan tersebut bukan hanya berlaku bagi berpindahan kepercayaan dari satu agama ke agama yang lain, tetapi juga termasuk perubahan pandangan terhadap agama yang dianutnya. sendiri.

d. Selain faktor kejiwaan dan kondisi lingkungan maka perubahan itupun disebabkan faktor petunjuk dari yang Maha Kuas (Jalaludin, 2011: 362)

Dengan demikian yang dimaksud konversi agama adalah perubahanatau berpindahnyapada diri seseorang dari keyakinan atau agama terdahulu ke agama yang baru, baik secara proses yang panjang atau prosesnya mendadak. Dalam konversi agama yang terjadi di Kecamatan Gondangrejo, pada umumnya perubahan agama prosesnya mendadak, karena suatu kepentingan dalam administrartif proses pernikah. Warga yang melakukan konversi agama yang didaftarkan melalui KUA ini memiliki argumentasi yang sangat beragam, sesuai dengan kondisinya masing-masing. Berdasar pada jawaban- jawaban calon muallaf di KUA Gondangrejo, alasan mereka berkonversi agama bisa dipilah menjadi empat yaitu, pertama, ingin menjadi musim yang sesungguhnya. Sebagaimana yang dalam kasus 
konversi keluarga SW mereka berkonversi dari non muslim ke Muslim dengan alasan mendasar yaitu kagum dan salut dengan kehidupan masyarakat muslim yang penuh kerukunan, damai, ramah pergaulan yang diatur sedemikian rupa. Keluarga ini sering memperhatikan tetangga mereka yang muslim menghadiri pengajian kelihatan baik dan menyenangkan, sehingga waktu berjalan menumbuhkan keinginan yang kuat dari keluarga untuk menjadi muslim yangsesungguhnya. Setelah hari melafadzkan ikrar dua kalimah syahadat, mereka kemudian dibimbing oleh tokoh agama setempat tersebutmemperbarui pernikahan mereka atau yang sering disebut dengan istilah "mbangun nikah". Kalau sebelumnya mereka menikah dengan tatacara Kristen, kemudian setelah ikrar mereka melaksanakan pernikahan secara Islam. Memperbarui nikah disini dengan mengucapkan ijab qobul yang dilaksanakan dihadapan tokoh agama yang dipercaya dengan mahar yang disepakati, dan juga disaksikan 2 orang saksi. Bedanya pada pembaharuan nikan pasca konversi agama ini tidak dicatatkan kembali di pemerintahan. Sebab secara hukum negara perpindahan Agama atau konversi Agama tidak akan menghapus status pernikahan resmi mereka, maka akad nikah sebelum keduanya masuk Islam adalah sah dalam pandangan Syari'at Islam. Membangun nikah dikalangan mualaf ini dilakukan bertujuan untuk memantapkan hati mereka saja karena dulunya mereka menikah secara Kristen dan setelah menjadi mualaf mereka menikah lagi. Hal ini dirasakan perlu sebab suami istri yang melaksanakan akad nikah semasa keduanya belum beragama Islam dan kemudian hari memeluk agama Islam, merasa pernikahan yang awal dilaksanakan kurang sempurna. Termasuk juga alasan adanya kehati-hatian kalau hubungan suami istri menjadi tidak halal atau terjadi perzinahan.

Selain keluarga SW di atas, alasan yang hampir sama juga digunakan oleh SM (23 tahun) mengemukakan bahwa ia berkonversi menjadi seorang muslim karena tertarik dengan keseharian ibunya yang menjadi muallaf sejak tahun 2004. Septia begitu kagum dengan kepribadian ibunya yang sangat berbeda setelah menjadi muallaf, dimana sang ibu menjadi lebih sabar, lebih bijaksana penuh kasih sayang serta lebih religius. Dengan izin restu dari ayahnya yang masih non muslim dan juga ibunya akhirnya pada September tahun 2010 SM mantap menjadi muallaf dengan mengucapkan 2 kalimah syahadat dihadapan tokoh agama dikampungnya Sugihwaras, Ds. Selokaton. Dia menjalani aktifitas ibadah sebagai muslim melalui bimbingan ibunya sendiri. Seiring waktu untuk memperoleh pengakuan secara administrasi pengurusan KK, KTP akhirnya SM dengan didampingi ayah dan ibunya melafadzkan 2 kalimah syahadat lagi dihadapan Kepala KUA Kec Gondangrejo pada Agustus 2015. Dua tahun setelah itu ketika ke KUA lagi SM mendaftarkan pernikahan dengan calon suaminya yang muslim.

Demikian juga dengan DF (17 tahun ) dan AA (21 tahun) warga Tegalsari Selokaton yang sebelumnya beragama Katholik juga mengungkapkan bahwa ia masuk ke Islam karena ingin menjadi muslim yang sejati. DF dan AA adalah kakak beradik, sejak SD ia dirawat oleh neneknya yang tinggal di Desa Selokaton. Ayah dan Ibunya bekerja dan tinggal di Jakarta dan beragama kristen. Tinggal bersama neneknya yang seorang Muslim mengajarkan kepada DF dan AA kecil untuk berbaur dan bermain bersama anak-anak lainnya yang mayoritas muslim, ikut TPA (Taman Pendidikan Al-Qur'an) di Masjid terdekat dengan rumah neneknya. Sampai akhirnya tidak hanya TPA yang diikuti tapi juga ikut melaksanakan Sholat wajib berjamaah di masjid, dan di bulan Ramadhan ikut menjalanipuasa layaknya seorang 
muslim. Hal ini dilaksanakan terus menerus hingga Usia mereka beranjak dewasa. Mengetahui hal ini kedua orang tua DF dan AA memberi kebebasan terhadap mereka asal kedua anaknya tersebut mampu menjaga agamanya sebagai muslim dan tetap hormat kepada kedua orang tuanya.

Untuk kepentingan admistrasi sebagai seorang muslim (dalam KK dan KTP masih beragama non muslim ) akhirnya keduanya memproses perpindahan Agama mereka ke KUA (Kantor Urusan Agama) Kec. Gondangrejo. Mereka melakukan konversi dan melaporkan keislaman merekauntuk mendapatkan layanan sipil keagamanan, seperti pencantuman agama dalam kolom KTP, KK atau surat administerasi kependudukan lainnya. Hal ini sesuai dengan aturan pemerintahan bisa mengganti status Agama dalam KK, KTP atau surat administrasi lainnya setelah mendapat Surat keterangan masuk Islam dari Kantor Kementerian Agama Kabupaten atau Kantor Urusan Agama Kecamatan sesuai domisili yang bersangkutan atau bisa diproses di kabupaten atau kecamatan lain setelah tinggal minimal 6 bulan di daerah tersebut. Kedua, alasan keperluan pernikahan. Akibat tidak diaturnya dalam Undang- Undang perkawinan yang memperbolehkan pasangan nikah beda agama di Indonesia, maka setiap pasangan yang mempunyai keyakinan berbeda harus menyatukan agama yang sama.

Sebagaimana diketahui bahwa dalam aturan di Undang-Undang Pernikahan Tahun 1974 pasal 2 (ayat 1) "Perkawinan adalah Syah apabila dilakukan menurut hukum masingmasing Agamanya dan Kepercayaannya itu”. Dengan ini berarti setiap Warga Negara Indonesia yang akan melaksanakan pernikahan harus melewati lembaga agama masingmasing dan tunduk terhadap aturan pernikahan setiap agamanya. Inilah yang menjadi dasar atau alasan utama seseorang melakukan konversi agama untuk melancarkan pernikahan mereka. Akibatnya ketika dua insan berbeda keyakinan, ketika akan melangsungkan pernikahan, maka lembaga agama tidak dapat menerima dan tidak dapat menikahkan mereka kecuali salah satunya mengikuti agama pasangan. Bagi yang beragama Islam dicatatkan di KUA dan bagi Non Muslim dicatatkan di Kantor Pencatatan Sipil. Kondisi masyarakat Gondangrejo yang plural dan heterogen, mempunyai keanekaragaman agama, namun tetap bisa menghormati dan bergaul antara satu sama lain. Hazairin, (1986: 2) secara tegas menafsirkan pasal 2 ayat 1 beserta penjelasannya dengan menyatakan "bagi orang Islam tidak adakemungkinan untuk kawin dengan melanggar aturan agamanya sendiri. Demikian juga bagi orang Kristen dan orang Hindu atau Budha seperti yang dijumpai di Indonesia."

EPP (23 Tahun) mengemukakan bahwa ia melakukan konversi agama ke Islam karena alasan untuk mempermudah administrasi pernikahan. Demikian juga dengan S (25 tahun) warga desa Rejosari dan beberapa muallaf yang lainnya melakukan konversi karena dalam keluarga pasangan pengantin sepakat bahwa harus satu agama, tidak boleh beda agama. Dalam kasus ini S beragama non-muslim, sedangkan pasangannya beragama Islam. Maka untuk mempermudah proses pernikahannya EPP, S, dan yang lainnya kemudian melakukan konversi menjadi mualaf muslim. Senada dengan dua kasus di atas, KTU yang sebelumnya beragama non-muslim menjalani proses konversi menjadi seorang muslim karena dia menyadari bahwa dia tidak akan bisa menikah dengan calon istrinya kalau mereka berbeda agama. Maka sebagai solusinya KTU kemudian memilih untuk meninggalkan agamanya yang lama, dan menjadi seorang muslim. Sebagian besar dari warga Kecamatan Gondangrejo melakukan konversi Agama adalah demi alasan ini. Kondisi ini ada yang 
berlangsung lama (menjadi muallaf yang sebenarnya ada juga yang sifatnya sementara (setelah menikah salah satu diantara mereka kembali ke agama semula).

Ketiga, alasan keluarga dan kebahagiaan anak. Dalam hal ini kasus yang dialami oleh RA (22 tahun) warga Bonoroto Plesungan yang melakukan konversi keagama Islam karena orang tua yang mendorong anaknya untuk masuk Islam. Orang tua tersebut menyadari bahwa anaknya terlihat bahagia karena memeluk agama Islam,meskipun demikian keluarga yang lainnya tetap memeluk agamaKristen. Dalam perjalanannya justru keluarga ini mendukung penuh usaha Rini untuk mempelajari Islam secara lebih baik. Rini bermaksud melakukan konversi agama mendatangi Kantor Urusan Agama Kec. Gondanrejo diantar dan didampingi sendiri oleh ayahnya yang beragama non-muslim, ayahnya mengatakan "ikhlas ketika anaknya pindah agama menjadi seorang muslim karena saya tahu anak saya bahagia dengan memeluk agama Islam."

Keempat, alasan untuk mengurus adminstrasi kependudukan anggotakeluarga. Hal ini secara umum masyarakat yang melakukan konversi merasa bahwa mengurus administrasi kependudukan dengan menggunakan agama islam itu jauh lebih mudah daripada menggunakan agama lainnya. Seperti yang telah ditulis diatas bahwa dalam aturan pemerintahan bisa mengganti status Agama dalam KK, KTP atau surat administrasi lainnya setelah mendapat Surat keteranga masuk Islam dari Kantor Kementerian Agama Kabupaten atau Kantor Urusan Agama Kecamatan sesuai domisili yang bersangkutan atau bisa diproses di kabupaten atau kecamatan lain setelah tinggal minimal 6 bulan di daerah tersebut. Untuk sampai pada konversi tersebut mereka memiliki proses yang sangat beragam. Setidaknya prosesnya ada yang diawali dengan konsultasi dengan aparat desa. Mereka meminta penjelasan mengenai bagaimana cara bisa masuk Islam. Minta bimbingan Tokoh agama terdekat untuk bisa masuk islam dan mendapatkan bimbingan seterusnya dalam proses mendalami Agama Islam. Namun juga ada yang langsung datang ke KUA untuk minta di syahadatkan dan minta surat ikrar sahadat masuk Islam. Ketika di KUA pun warga yang akan melakukan konversi agama akan dibimbing dan mendapatkan penasehatan dan penyuluhan sebelum akhirnya mantap untuk mengucapkan dua kalimah syahadat. Selain itu juga ada yang melakukan ikrar keislaman mereka dengan jalan meminta takmir masjid untuk membimbing syahadat mereka. Pola lainnya berangkat dari adanya pergaulan dengan teman dan keluarga lainnya yang sudah terlebih dahulu memeluk agama Islam. Mereka tertarik dengan ahlak dan pola beragama umat Islam. Serta karena kebutuhan untuk mempermudah proses pelaksanaan pernikahan.

\section{Pertumbuhan Sikap Beragama Pasca Konversi Agama}

Dalam kenyatananya konversi agama dalam pernikahan ini tidak lepas dari persoalan pertumbuhan sikap keberagamaan yang dialami oleh seseorang. Kematangan beragama seseorang ini dapat dilihat dari sejauh mana seorang tersebut memahami pesan keagamaan, menghayati dan kemudian mempraksiskan dalam kehidupan kesehariannya. Seseorang akan berupaya menjadi penganut agama yang baik, sebab kehidupannya merupakan cerminan dari ketaatannya pada agama. Dalam kasus SW sekeluarga ini memeluk Islam dan berharap dengan masuk Islam bisa mendatangkan ketenangan dan kecintaan. Maka SW bersama keluarganya kemudian melakukan konversi dengan keyakinan yang tinggi bahwa akan ada kebahagiaan setelah menjalani konversi agama ini. Harapannya tentu bukan hal yang tiba- 
tiba muncul, akan tetapi telah mengalami proses pencarian yang panjang, mulai bertanya tentang Islam, belajar dari media dan juga meminta nasehat dari Kyai atau Ustad yang ada di Desa tersebut. Proses ini kemudian menjadi penanda dari keyakinan baru mereka. Demikian juga dengan DF dan AA yang semenjak kecil telah hidup bergaul dengan keluarga muslim di lingkungannya, yangmereka nilai baik, empatik dan tidak diskriminatif. Selama bertahun tahun keduanya hidup dengan neneknya yang ada di Gondangrejosedangkan kedua orang tuanya tinggal di Jakarta. Jauhnya dari orang tua tersebut kemudian memunculkan ruang kasih sayang yang hilang, maka ia menemukan kasih sayang tersebut di tengah masyarakat sekitarnya. Maka ia kemudian belajar beribadah sebagai seorang muslim, dan ketika sudah dewasa mengurus keperluan administerasi kependudukan ia akhirnya menentukan putusan untuk memeluk agama Islam secara penuh.

Dalam kasus yang dijalani oleh warga SW sekeluarga, dan DF serta AA ini dalam psikologi agama disebut healty minded atau beragama secara sehat, lawan dari sick Soul atau beragama secara sakit.(Walter Houston Clark: 154) Healty mind adalah perkembangan kepribadian yang terbangun atas dasar sikap positif terhadap kehidupan. Apapun yang ada dalam kehidupan disikapi secara positif dan wajar. Sedangkan sick soul merupakan tipe perkembangan kepribadian yang lebih asketis dan menutup diri. Seseorang yang mengalami pertumbuhan seperti ini memiliki kecenderungan sangat taat terhadap agamanya, merasa sangat berdosa dan tidak memiliki gairah untuk hidup bersenang-senang.

Dalam kasus di Gondangrejo karakteristik beberapa orang yang berkonversi agama memiliki karakter healty minded,yang terlihat dari;optimis dan gembira, dalam pengertian orang dengan tipe demikian akan menghayati segala bentuk agamanya dengan perasaan optimis. Segala bentuk dan pasang surut dalam kehidupanya adalah hal yang disikapi secara wajar, buah dari kesalahan sebagai manusia, maka solusinya adalah memperbaiki diri.Pada umumnya bersifat terbuka yang ditandai secara dewasa bisabersikap bijaksana atas pengalaman buruk yang pernah dilakukan atau dialami. Terlihat menyenangi ajaran yang terbuka. Salah satu karakter tipe ini adalah senang pada pola beragama yang terbuka, menunjukkan tipe keberagamaan yang bebas, dan memiliki komitmen sosial yang tinggi. Sebagai kebalikan dari tipe healty minded ini adalah tipe pertumbuhan sakit (sick) akan memiliki karakter sangat berbeda.

Pada umumnya mereka memiliki karakter tempramental, merasa jauh dari Tuhan, tidak percaya diri dan terkesan mudah curiga. Umumnya mereka mengalami persoalan seirus kemudian menyebabkan adanya perubahan sikap yang mendadak terhadap keyakinan agama (suffering).Sikap keberagamaan ini sering ditemui pada orang-orang yang pernah mengalami kondisi kehidupan keagamaan yang terganggu. Orang tersebut meyakini dan menjalankan ajaran agama mereka bukan berasal dari kematangan dalam beragama yang berkembang secara normal bertahab semenjak dari anak-anak sampai dengan usia dewasa sebagaimana lazimnya perkembangan keberagamaan secara normal. Orang ini meyakini dan menjalankan agama mereka didasarkan pada adanya suatu penderitaan batin yang mungkin disebabkan adanya musibah, konflik dan sebab lainnya yang sangat mendasar.

Dalam kasus konversi dalam pernikahan di Gondangrejo ini, terlihat ada faktor internal, yang mendasari terjadinya konversi. Faktor tersebut datang dari diri sendiri, meliputi adanya konflik dan keraguan dalam diri seseorang, adanya perasaan jauh dari Tuhan, sikap pesimis dan karakter introvert. Konflik dan keraguan dalam diri sendiri sering 
disebabkan adanya keraguan pada keyakinan yang selama ini diyakini. Akibatnya mereka menjadi orang yang berusaha menemukan makna terdalam dari keyakinan orang tersebut. Sebagaimana yang dialami oleh Hadi Kriswanto yang merasa ada perasaan jauh dari Tuhan juga menjadi penyebab dia berkonversi. Perasaan ini kemudian mendorong orang untuk sekuat tenaga berupaya mengabdikan diri mereka kepada Tuhan secara sungguh-sungguh.

Disisi lainnya juga terdapat faktor eksternal berkaitan dengan adanya guncangan jiwa yang dialami seseorang. Dalam hal ini keguncangan seringkali mengantar seseorang pada pemahaman bahwa dia harus kembali kepada persoalan keagamaan, sebab selama ini dirasa jauh dari persoalan tersebut. Faktor eksternal ini juga berkaitan dengan keinginan untuk mendapatkan kemudahan dalam hidup, sehingga ia berniat kembali kepada jalan agama. Misalnya yang dialami oleh pelaku konversi yang motif uatamanya adalah untuk memperlancar proses pernikahan.

\section{Orientasi Keagamaan Masyarakat Gondangrejo Pasca Konversi Agama}

Konversi agama dalam pernikahan di Gondangrejo sangat penting juga untuk dilihat dari sisi orientasi, sikap dan perilaku keberagamaannya. Secara umum hak ini dapat dipilah menjadi dua yaitu intrinsik dan ekstrinsik, yang lahir dari diri individu dan hidup sebagai keyakinan, mengingat diluar diri berguna bagi diri sendiri. Dalam kasus konversi yang dialami oleh SW adalah muncul orientasi secara intrinsik, yang berangkat dari adanya motivasi keyakinan yang dinyatakan, diperlihatkan oleh seseorang dan dilihat oleh orang lain. Secara intrinsik motivasi seseorang akan setuju dengan pernyataan dirinya. "saya nyatakan dengan keras untuk mengangkat agama saya kedalam semua janji-janji hidup", agama dan keyakinan saya adalah apa yang ada pada diri saya dan digunakan pandangan hidup", doa-doa saya nyatakan dimana saya sendirian mengangkat banyak makna dan emosi personal semua itu nyatakan selama saya melayani”.

Karakteristik tipe keberagamaan intrinsik akan mempunyai sikap kedewasaan dalam beragama yang akan mengarah pada pembangunan kapasitas yang komplit terhadap komitmen pada diri sendiri, yakin dan tidak terpengaruh dari luar dirinya yang berakibat pada merusak sikap independensinya. Sedangkan dalam konversi yang dilakukan oleh EP terlihat adanya orientasi ektrinsik. Orientasi ektrinsik ini agak lebih menginternalisasi keyakinan, dirawat untuk sesuatu yang lain atau mendapatkan sesuatu yang menjadi kepentingan dirinya.Misalnya kita hanya berdoa kalau merasa perlu memohon sesuatu. Doa-doa kita isinya sebagian besar hanya permohonan saja. Akibatnya, kalau tidak ada yang kita rasa perlu untuk dimohonkan, kitapun tidak merasa untuk berdoa. Disini orientasi keberagamaan ini membentuk sikap beragama yang barter selalu berharap kembali pada diri sendiri. Kedua tipe ini memiliki dampak pada sikap keagamaan seseorang. Ekstrinsik seseorang membutuhkan partisipasi yang lain untuk penyatuan dengan agamanya sebagai orientasi keagamaannya.

Dari kedua type orientasi ini intrinsik dan ektrinsik merupakan bagian dari pengalaman setiap orang dalam memeluk agamanya dan berdampak pada sikap keagamaan yang diperlihatkan dalam hidup sehari-hari yang nampak. Dalam kasus konversi diatas keberagamaan intrinsik, adalah keseluruhan perilaku seseorang yang diusahakan berdasarkan agama yang diyakinininya. Sedangkan keberagaman ektrinsik artinya suatu perilaku seseorang yang menggunakan agama untuk tujuan-tujuan yang lain, seperti yang dicontohkan diatas yaitu adanya kepentingan. Adanya konsistensi antara keyakinan beragama dengan 
perilaku seseorang dalam kehidupan sehari-hari atau sebuah komitmen keberagamaan.

Dalam kasus konversi di Gondangrejo paling tidak terdapat tiga konsep tentang orientasi beragama pasca konversi yaitu religion as end (agama sebagai tujuan akhir), religion as mean (agama sebagai alat), dan religion as quest (agama sebagai pencarian).Pada persoalan agama sebagai tujuan akhir. Tatkala orientasi agama dibelokkan ke arah the end, maka agama akan masuk perangkap finalitas yang paripurna, sehingga ia kebal (imune) dari kritik. Pemeluk agama yang berpegang pada orientasi ini akan cenderung kurang memiliki pemahaman kritis terhadap agama, terutama pada aspek pembedaan bagian mana wilayah agama murni dan bagian mana wilayah tafsir atas agama. Mereka kerap kali bersikap taken for granted terhadap agama. Pada akhirnya, agama kian terjangkit virus stagnasi spiritual, dan cenderung menguatkan eksklusivisme para pemeluknya.

Ketika tingkat kritisisme terhadap agama lenyap sama sekali, dan fanatisme semakin mengakar kuat dalam keyakinan si pemeluk agama, maka agama dengan mudah akan dimanipulasi oleh kepentingan politik dan kekuasaan. Jadi hakikatnya para pemeluk agama yang berorientasi religion as end dan religion as mean hanya memanfaatkan agama sebagai justifikasi perilaku mereka saja yang belum tentu sesuai dengan nilai-nilai universal agama. Maka dengan jelas dapat dikatakan bahwa, perilaku seperti itu sama artinya dengan tindak "mematisurikan agama". Untuk itu, diperlukanorientasi lain dari agama, berbeda dari dua orientasi sebelumnya. Dalam kasus religion as quest. Individu dengan orientasi 'pencarian' tidak akan menganggap agama sebagai sesuatu yang sudah final dan paripurna. Orientasi agama seperti ini membentuk pemeluk agama menjadi pribadi-pribadi yang anti kesempurnaan, tapi tetap mempunyai visi ke depan untuk mengejar kesempurnaan secara terus menerus melalui berbagai cara.

Dalam konversi ini efek positif yang timbul ketika individu memilih keagamaan yang berorientasi pencarian, paling tidak adalah tumbuhnya kritisisme atau sensitivitas terhadap agama. Orientasi beragama sesorang sangat terkait dengan sikap dan perilaku keberagamaan. Sikap merupakan perasaan seseorang tentang obyek, aktivitas, peristiwa dan orang lain. Perasaan ini menjadi konsep yang merepresentasikan suka atau tidak sukanya (positif, negatif, atau netral) seseorang pada sesuatu. Sikap muncul dari berbagai bentuk penilaian. Sikap dikembangkan dalam tiga model, yaitu afeksi, kecenderungan perilaku, dan penalaran. Respon afektif adalah respon fisiologis yang mengekspresikan kesukaan individu pada sesuatu. Kecenderungan perilaku adalah indikasi verbal dari maksud seorang individu. Respon kognitif adalah pengevaluasian secara kognitif terhadap suatu objek sikap. Kebanyakan sikap individu adalah hasil dari proses sosial yang terjadi dari lingkungannya.

Melalui pertimbangan fungsi afektif, kognitif, dan psikomotoriknya, pada saat-saat tertentu individu akan meyakini dan menerima tanpa keraguan bahwa di luar dirinya ada sesuatu kekuatan yang maha Agung yang melebihi apa pun, termasuk dirinya. Penghayatan keagamaan tidak hanya sampai kepada pengakuan atas kebaradaan-Nya, namun juga mengakui-Nya sebagai sumber nilai-nilai luhur yang abadi yang mengatur tata kehidupan alam semesta raya ini. Oleh karena itu, manusia akan tunduk dan berupaya untuk mematuhinya dengan penuh kesadaran dan disertai penyerahan diri dalam bentuk ritual tertentu, baik secara individual maupun kolektif, secara simbolik maupun dalam bentuk nyata kehidupan sehari-hari. 
Disinilahsebenarnya dalam konversi agama di Gondangrejo sikap keberagamaan akan mengarahkan seseorang menciptakan sistem makna untuk mengarahkan perilaku kesalehan dalam kehidupan. Mereka akan berusaha memenuhi kebutuhan dasar, yaitu memberikan kontribusi terhadap terwujudnya kehidupan religiositas, yang hidup dengan sendirinya di dalam setiap dada para individu.Pengalaman keagamaan ini tumbuh dan berkembang hingga mencapai tahap kematangan beragama, sebagaimana perkembangan dan kedewasaan yang terjadi pada fisik atau jasmani seseorang. Prilaku agama seseorang sangat dipengaruhi oleh faktor internal, yaitu inner personal orang yang beragama itu sendiri maupun pengaruh dari eksternal. Faktor internal meliputi konstitusi tubuh; struktur dan keadaan fisik; koordinasi motorik; kemampuan mental dan bakat khusus (intelegensi tinggi, hambatan mental, bakat khusus), dan emosionalitas, dan faktor eksternal, seperti keluarga, pendidikan, dan lingkungan sekitarnya. Semua faktor ini ikut mempengaruhi perkembangan kematangan keberagamaan seseorang.

Kematangan beragama, disatu sisi, dapat dipahami sebagai puncak tertinggi dari perkembangan beragama, atau dapat di pahami sebagai suatu konsep ideal, dimana seluruh perkembangan beragama dapat diukur dan bandingkan. Dalam arti yang kedua ini beberapa ahli psikologi (agama) telah mengemukakan kriteria-kriteria kematangan beragama yang dapat digunakan sebagai standar atau ukuran (measure) penilaian, apakah keberagamaan seseorang itu telah mencapai kematangan beragama (religious maturity) atau tidak (religious immaturity). Kunci utama kehidupan yang sejati adalah hasil kematangan beragama dapat ditemukan pada dua karakter terakhir yang telah disebutkan di atas, yaitu perasaan kebahagiaan dan kebebasan, serta pergeseran pusat emosional menuju cinta dan kasih sayang yang harmonis.

\section{Konversi Agama Dalam Prespektif Fiqh Dan Hak Asasi Manusia (HAM)}

Kebebasan beragama dalam kacamata hak asasi manusia mempunyai posisi yang kompleks. Dalam Konfigurasi ketata-negaraan, kebebasan beragama mempunyai posisi yang penting juga. Sejumlah besar kegiatan manusia dilindungi oleh pasal- pasal mengenai kebebasan beragama, kebebasan berekspresi, dan kebebasan berpolitik (Sulistiyoni: 2008). Kebebasan beragama muncul sebagai hak asasi yang paling mendasar dalam instrument instrument politik nasional dan internasional. Namun demikian, di sisi lain menguraikan hubungan antara agama dan Hak Asasi Manusia bukanlah perkara mudah walaupun dalam konteks Islam, kebebasan beragama adalah sesuatu yang inherent dan intrinsic dan diakui secara verbal dalam Al- Qur'an. Menurut Hammudah 'Abdati, di sisi kaca mata Islam, "setiap individu dilahirkan bersih (fitrah) dari perbudakan, dosa, dan kasta." Walaupun manusia dilahirkan dalam kebebasan, kebebasan yang diberikan tidaklah bersifat mutlak kerana kebebasan mutlak hanya milik Allah SWT. Dalam Islam, setiap individu mempunyai hak kebebasan beragama, mengamalkan dan beribadat mengikut agama yang dianutinya. Justru itu, setiap manusia juga diberi kebebasan mutlak untuk memilih manamana agama untuk dianutinya. Ini dijelaskan dalam al-Qur' an: "Maka barang siapa yang ingin (beriman) hendaklah ia beriman, dan barang siapa yang ingin(kafir) biarlah ia kafir. " Al-Quran juga secara terang menekankan bahwa dalam keadaan mana pun seseorang itu tidak boleh dipaksa untuk menganuti agama atau kebercayaan yang berlawanan dengan kehendaknya. Ini sesuaidengan firman Allah: "Tidak ada paksaan untuk (memasuki) agama (Islam)". 
Islam tentu mengakui kebebasan beragama, hanya saja kebebasan beragama dalam Islam bersifat ibtidaiy (permulaan), dan tidak intiha'iy (diakhir). Artinya, seseorang pada awalnya dibebaskan untuk memilih agama yang ia yakini. Islam juga tidak memaksa umat agama lain untuk memeluk Islam. Pada tingkatan inilah, Islam mengakui kebebasan beragama. Setelah seseorang memeluk Islam, maka berarti ia telah mengikatkan dirinya pada Islam. Ia tidak lagi memiliki kebebasan untuk keluar Islam, termasuk mengingkari doktrin-doktrin umum dalam Islam. Namun sebagian dari mereka yang menganut kebebasan bergama, dimana HAM dan Al-Qur'ãn (khususnya dalam Q.S. Yunus : 99 "Apakah engkau, memaksa manusia, supaya mereka menjadi orang-orang yang beriman semuanya”?) lebih memilih untuk tidak memberikan hukuman mati, karena mereka beranggapan bahwa apa yang dilakukan individu khususnya ketika meninggalkan agama, akan menjadi dosa pribadi.

Dengan demikian hal tersebut menjadi urusan pribadi dengan Tuhan.Sebagian orang merasakan dihapusnya hak atas harta warisan, pengasingan, hilangnya hak perwalian atas anak, hilangnya hak -hak sebagai suami maupun istri,kesemuanya tersebut sebagai dampak negatif berupa hukuman dalam tindakan.Di lain sisi dari proses konversi agama terdapat dampak positif, yakni: individu lebih memaknai peran agama di dalam menjawab kebutuhan hidupnya. Dengan memilih dan memutuskan untuk melakukan konversi agama, individu dapat mengevaluasi diri sendiri terkait dengan penghayatannya terhadap iman kepercayaannya dalam satu agama.

\section{KESIMPULAN}

Konversi agama sebagai hak yang melekat dalam diri individu dalam praktiknya tidak selalu mudah, akan tetapi mengalami berbagai tantangan. Dalam kasus konversi di Gondangrejo Karanganyar persoalan konversi tidak lepas dari adanya pertumbuhan keberagamaan yang dialami oleh seseorang. Perkembangan keberagamaan seseorang secara umum dibedakan menjadi healty minded dan sick Soul. Bagi Orang yang memiliki kepribadian sick soul dengan segala kepasrahan kepada Tuhan membuat mereka menjadi orang yang tidak mudah menyalahkan atau menuntut orang lain. Sedangkan orang dengan kepribadian healty minded memiliki kecenderungan memiliki pandangan keberagamaan yang terbuka, mau menerima pola keberagamaan orang lain yang beda dengan dirinya. Sedangkan orientasi keberagamaan seseorang dalam kasus Gondangrejo ini mengarahkan seseorang menciptakan sistem makna untuk mengarahkan perilaku kesalehan dalam kehidupan, yang puncaknya pada kematangan beragama.

\section{DAFTAR PUSTAKA}

Jalaluddin Rahmat, Psikologi Agama; Sebuah Pengantar (Bandung: Mizan Media Utama, 2003)

William James, Perjumpaan Dengan Tuhan; Ragam Pengalaman Religious Manusia (terj) Gunawan Admiranto (Bandung: Mizan, 2004)

Walter Houston Clark, The Psicology of Religion an Introduction to Religious Eksperience and Behavior (New York: The Macmillan Company, 1968) 
Rusli, "Konversi Agama: Tinjauan Fiqh Terhadap Haddriddah”, dalam http://bangrusli.blogspot.com/2011/06/konstruksi-mazhab-fikih.htm, dikutip tanggal 5 Desember 2018.

Departemen Agama RI, 1986, Al-Qur'an dan Tafsirnya, Jakarta: Proyek Pengadaan Kitab Suci al-Qur'an. Jilid I

Departemen Agama RI, Al-Qur'an danTerjemahan, (Semarang:Toha Putra, 2007)

Hazairin, Tinjauan Mengenai Undang-Undang Perkawinan Nomor: 1-1974, Jakarta: Tinta Mas. Cet kedua' 1986,

Puspito, Hendro, Sosiologi Agama, ( Gunung Mulia 1984 )

Jalaluddin, Psikologi Agama, (Jakarta : Rajawali Press, 2011) 